\title{
Kinetika vulkanisasi dan sifat mekanis komposit acrylonitrile butadiene rubber (NBR)
}

\section{Vulcanization kinetics and mechanical properties of acrylonitrile butadiene rubber (NBR) composite}

\author{
Arum Yuniari*, Ike Setyorini, Hesty Eka Mayasari \\ Balai Besar Kulit, Karet, dan Plastik. J1 Sokonandi No. 9 Yogyakarta 55166, Indonesia \\ *Penulis korespondensi. Telp.: +6274 512929, 563939, Fax.: +6274 563655 \\ E-mail: arumyuniari@yahoo.com
}

Diterima: 5 September 2016 Direvisi: 13 Oktober 2016 Disetujui: 17 Oktober 2016

\begin{abstract}
The aim of this research was to study the effect of vulcanization temperature on mechanical properties and curing kinetics of NBR composites. The composites were formulated by using two types of carbon black i.e. $N$-330 and N-774. The curing kinetics was determined using Moving Die Rheometer. The network formation processes were related to torque and time. The vulcanizates were obtained by compression molding in a hydraulic press at $150^{\circ} \mathrm{C}$ and $160^{\circ} \mathrm{C}$. The mechanical properties observed include tensile strength, elongation at break, hardness, and tear strength. Kinetics studies were approached by Arrhenius equation and the reaction mechanism was assumed following first order reaction. The results showed that curing kinetics can be approached by the equation from the rheometer data. The surface area of carbon black strongly influenced the mechanical properties and rate constant (k) of NBR composite. Carbon black N-330 can be used as a desirable reinforcing filler which gave a higher mechanical properties than the other type of carbon black.
\end{abstract}

Keywords: curing kinetics, NBR, temperature, mechanics.

\section{ABSTRAK}

Tujuan dari penelitian ini adalah mengetahui pengaruh suhu vulkanisasi terhadap sifat mekanis dan kinetika vulkanisasi komposit NBR. Formulasi komposit menggunakan dua macam carbon black yaitu N-330 dan N-774. Kinetika vulkanisasi ditentukan dengan alat Moving Die Rheometer, dimana proses vulkanisasi berlangsung dikaitkan dengan torsi dan waktu. Proses pembuatan vulkanisat menggunakan hydraulic press pada suhu $150^{\circ} \mathrm{C}$ dan $160^{\circ} \mathrm{C}$. Sifat mekanis komposit NBR yang diamati adalah tegangan putus, perpanjangan putus, kekerasan dan kuat sobek. Kinetika vulkanisasi didekati dengan persamaan Arrhenius dikaitkan dengan mekanisme reaksi dan diasumsikan orde satu. Hasil penelitian menunjukkan bahwa kinetika vulkanisasi dapat didekati dengan persamaan dari data reometer. Surface area carbon black sangat kuat mempengaruhi sifat mekanis dan rate constant (k) dari komposit NBR. Carbon black N 330 merupakan bahan pengisi yang bersifat sebagai penguat dan memberikan sifat mekanis tertinggi dibandingkan carbon black jenis lainnya.

Kata kunci: kinetika vulkanisasi, NBR, suhu, mekanis.

\section{PENDAHULUAN}

Elastomer merupakan polimer bercabang dengan modulus elastisitas rendah dan kemampuan deformasi tinggi sehingga dimungkinkan memiliki penggunaan lebih luas. Acrylonitrile butadiene rubber (NBR) merupakan kopolimer dari akrilonitril dan butadiena diproses dengan cara kopolimerisasi emulsi. Beberapa sifat yang dimi- liki NBR antara lain makin tinggi kadar akrilonitril maka ketahanan minyak, tegangan putus dan ketahanan kikis tinggi tetapi sifat pampat tetap (compression set) dan elastisitas menurun. NBR merupakan polimer sintetis mempunyai ketahanan minyak sangat baik tetapi sifat mekanisnya rendah. Hal ini disebabkan NBR bersifat non kristalin. Pada proses pembuatan produk karet dengan 
bahan baku NBR perlu diberi bahan pengisi agar diperoleh sifat mekanis tinggi. Beberapa bahan aditif yang digunakan untuk pembuatan produk karet: bahan pemvulkanisasi, akselerator, aktivator, anti oksidan, antidegradant, bahan pengisi dan plasticizer.

Bahan pengisi memegang peran penting dalam pembuatan produk karet. Penggunaan bahan pengisi untuk memperkuat sifat vulkanisat NBR telah dilakukan oleh beberapa peneliti. Carbon black merupakan bahan pengisi yang banyak digunakan dalam industri karet, karena bersifat sebagai penguat. Selama proses pembuatannya, carbon black berbentuk agregat. Bentuk dan derajat percabangan agregat disebut struktur. Struktur dari carbon black ditentukan oleh bentuk dan derajat percabangan. Penggunaan carbon black sebagai bahan pengisi pada elastomer NBR akan menghasilkan vulkanisat dengan sifat mekanis baik (Jovanovic et al., 2009; Mostafa et al., 2009). Indrajati et al. (2012) mempelajari pengaruh HAF/ SRF terhadap sifat karakteristik vulkanisasi, morfologi dan swelling vulkanisat NBR. Peningkatan struktur dari carbon black berpengaruh terhadap sifat kekerasan, modulus dan viskositas campuran (Allegra et al., 2008). Jovanovic et al. (2013) melaporkan penambahan carbon black pada komposit NBR/EPDM akan menaikkan torsi maksimum dan minimum, tetapi waktu scorch $\left(\mathrm{ts}_{2}\right)$ dan cure rate index (CRI) turun. Beberapa penelitian terkait komposit NBR telah dilakukan oleh beberapa peneliti antara lain: degradasi NBR dalam rapeseed biodiesel oleh Akhlaghi et al. (2015), pencampuran NBR dan NR menggunakan compatibilizer epoxidized natural rubber dilaporkan oleh Rajasekar et al. (2009). Mobilitas molekular dari kopolimer nano komposit NBR dengan bahan pengisi organoclay telah diteliti oleh Chung et al. (2008). Reaksi ikatan silang antara NBR dan copper sulfate dilaporkan oleh Yua et al. (2007).

Karakteristik vulkanisasi digunakan untuk mengetahui reaksi vulkanisasi yang ditunjukkan dari kurva torsi versus waktu yang diperoleh dari alat uji reometer (Fathurrohman et al., 2015). Model kinetik untuk mempelajari reaksi vulkanisasi sudah dipelajari oleh beberapa peneliti. Kinetika vulkanisasi dari komposit karet dapat dihitung dengan beberapa cara antara lain: swelling, tegangan putus, kekerasan, DSC, sulfur bebas dan ikatan sambung silang (Zaimova et al., 2011). Kinetika vulkanisasi dan sifat mekanis dari ethylene propylene diene monomer (EPDM) dipelajari oleh
Fathurrohman et al. (2015). Karakteristik vulkanisasi, sifat mekanis dan swelling dari campuran EPDM dan chloroprene rubber dengan bahan pengisi marble sludge oleh Ahmed et al. (2012). Jovanovic et al. (2013) telah mempelajari pengaruh carbon black terhadap kinetika vulkanisasi (energi aktivasi dan energi reversion), morfologi dan sifat termal dari campuran NBR/EPDM. Pada makalah ini akan dipelajari kinetika vulkanisasi dan sifat mekanis komposit NBR yang dibuat pada suhu vulkanisasi $150^{\circ} \mathrm{C}$ dan $160^{\circ} \mathrm{C}$ dengan bahan pengisi carbon black N330 dan N774.

\section{BAHAN DAN METODE Bahan Penelitian}

Bahan baku yang digunakan adalah: NBR merek Krynac $4975 \mathrm{~F}$ dengan viskositas mooney $\operatorname{ML}(1+4) 100^{\circ} \mathrm{C}(75 \pm 5)$, kadar ACN 48,5 $\pm 1,5 \%$, kadar volatil $\leq 5$, specific gravity 1,01, dan kadar $\mathrm{abu} \leq 0,7$. Bahan aditif yang digunakan adalah: carbon black jenis N330 (specific gravity 1,81 $\mathrm{g} / \mathrm{cm}^{3}$, absorpsi DBP $102 \mathrm{ml} / 100 \mathrm{~g}$, ukuran partikel 26-30 nm, luas permukaan 70-90 $\mathrm{m}^{2} / \mathrm{g}$ ) dan N774 (spesifik gravity $3,36 \mathrm{~g} / \mathrm{cm}^{3}$, absorpsi DBP $77 \mathrm{ml} / 100 \mathrm{~g}$, ukuran partikel 60-70 nm) ex. OCI sebagai filler, paraffin wax Antilux 654 A sebagai antioksidan, paraffinic oil dari Indrasari, seng oksida $(\mathrm{ZnO})$ ex. Indoxide dan asam stearat Aflux 42 $M$ ex. Rhein Chemie, sebagai pengaktif, TMQ ex. Kemai sebagai antioksidan, 6PPD ex. Starchem sebagai antiozonan, tiuram disulfida (TMTD) dibenzothiazyl disulfide (MBTS) ex. Shandong sebagai akselerator, serta sulfur ex. Miwon sebagai bahan pemvulkanisasi.

\section{Peralatan Penelitian}

Alat yang digunakan dalam penelitian ini meliputi alat proses dan alat uji terdiri atas: two roll mills, moving die rheometer MDR merek Gotech 3000 A, hydraulic press MN Vulcanizing Press, Spec XLB, D 400 x 400 x1, Hardness Shore A durometer, timbangan digital merek Denver, tensile strength tester merek Kao Tieh model KT 7010A seri 70287 kapasitas $500 \mathrm{~kg}$.

\section{Metode Penelitian}

NBR dan bahan tambahan ditimbang sesuai formulasi, selanjutnya digiling dengan two roll mills dengan suhu $40-50^{\circ} \mathrm{C}$. Waktu yang diperlukan untuk pencampuran selama 37 menit. Kompon yang diperoleh dikondisikan pada ruang kondisi pada suhu $23 \pm 2^{\circ} \mathrm{C}$ selama $24 \mathrm{jam}$. Setelah itu 
Tabel 1. Formulasi kompon NBR.

\begin{tabular}{lcccc}
\hline \multirow{2}{*}{ Bahan } & \multicolumn{4}{c}{ Jumlah, phr } \\
\cline { 2 - 5 } & NBR1 & NBR2 & NBR3 & NBR4 \\
\hline NBR & 100 & 100 & 100 & 100 \\
ZnO & 5 & 5 & 5 & 5 \\
Asam stearat & 1 & 1 & 1 & 1 \\
Paraffinic oil & 10 & 10 & 10 & 10 \\
C. Black N330 & 0 & 40 & 0 & 20 \\
C. Black. N774 & 0 & 0 & 40 & 20 \\
6 PPD & 2 & 2 & 2 & 2 \\
TMQ & 2 & 2 & 2 & 2 \\
Paraffin wax & 0,5 & 0,5 & 0,5 & 0,5 \\
MBTS & 1,5 & 1,5 & 1,5 & 1,5 \\
TMTD & 0,5 & 0,5 & 0,5 & 0,5 \\
Sulfur & 1,5 & 1,5 & 1,5 & 1,5 \\
\hline
\end{tabular}

kompon diuji dengan alat reometer pada suhu $150^{\circ} \mathrm{C}$ dan $160^{\circ} \mathrm{C}$ untuk mendapatkan data $\mathrm{ts}_{2}, \mathrm{t}_{90}$, $\mathrm{M}_{\mathrm{H}}$, dan $\mathrm{M}_{\mathrm{L}}$. Selanjutnya kompon di vulkanisasi menggunakan hydraulic press pada tekanan 150 $\mathrm{kg} / \mathrm{cm}^{2}$, suhu $150^{\circ} \mathrm{C}$ dan $160^{\circ} \mathrm{C}$ dengan waktu sesuai dengan reometer.

Pada penelitian ini komposit NBR dibuat menggunakan 2 (dua) jenis carbon black (N330 dan N774) sedang jumlah yang ditambahkan tetap. Adapun rancangan penelitian tertuang pada Tabel 1.

Pengujian waktu vulkanisasi dilakukan menggunakan reometer MDR merk Gotech 3000 A frekuensi $100 \mathrm{cpm}$ dan sudut 3 derajat dengan suhu $150^{\circ} \mathrm{C}$ dan $160^{\circ} \mathrm{C}$ menggunakan ASTM D 2084-11. Energi pencampuran kompon dicatat. Beberapa parameter kinetika curing mencakup $\mathrm{M}_{\mathrm{L}}$ (torsi minimum), $\mathrm{M}_{\mathrm{H}}$ (torsi maksimum), $\mathrm{t}_{90}$ waktu optimum vulkanisasi dan ts, (waktu scorch) diamati. Kinetika vulkanisasi didekati dengan persamaan Arrhenius dan diasumsikan reaksi orde

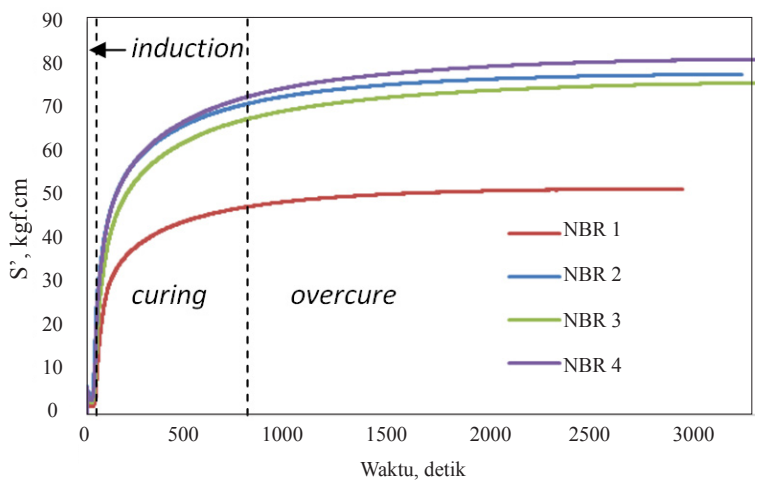

Gambar 1. Kurva vulkanisasi komposit NBR pada suhu $150^{\circ} \mathrm{C}$. satu.

Kompon NBR yang akan diuji sifat mekanisnya di vulkanisasi dengan hydraulic press pada tekanan $150 \mathrm{~kg} / \mathrm{cm}^{2}$, suhu $150^{\circ} \mathrm{C}$ dan $160^{\circ} \mathrm{C}$, waktu sesuai waktu optimum vulkanisasi $\left(\mathrm{t}_{{ }_{00}}\right)$. Pengujian sifat mekanis vulkanisat meliputi: tegangan putus dan perpanjangan putus, kuat sobek (ASTM D 412- 87), dan kekerasan (BS 903).

\section{HASIL DAN PEMBAHASAN}

\section{Studi Kinetika Vulkanisasi}

Karakteristik vulkanisasi komposit NBR dengan bahan pengisi carbon black ditentukan dengan peralatan reometer Gotech MDR 3000 A, dari peralatan tersebut diperoleh kurva torsi versus waktu. Data tersebut digunakan untuk mengevaluasi parameter kinetika.

Gambar 1 dan 2 merupakan kurva vulkanisasi komposit NBR dengan bahan pengisi carbon black N330, N774, dan N330/N774 pada suhu $150^{\circ} \mathrm{C}$ dan $160^{\circ} \mathrm{C}$. Proses vulkanisasi komposit

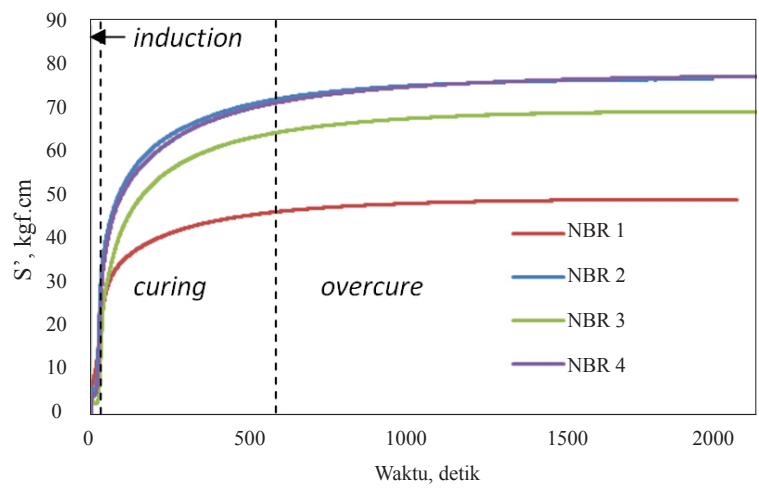

Gambar 2. Kurva vulkanisasi komposit NBR pada suhu $160^{\circ} \mathrm{C}$. 
NBR dengan bahan pengisi carbon black menggunakan sulfur sebagai bahan pemvulkanisasi. Hasil uji reometer menghasilkan kurva vulkanisasi yang terdiri dari 3 (tiga) tahap. Tahap pertama adalah waktu scorch $\left(\mathrm{ts}_{2}\right)$ /induction time merupakan waktu terjadinya reaksi kimia secara lambat antara karet dan aditif. Tahap tersebut merupakan waktu aman untuk proses vulkanisasi, pada tahap induksi terjadi proses awal carbon black berinteraksi dengan matriks polimer menghasilkan ikatan silang fisis yang digambarkan dengan kenaikan $\mathrm{M}_{\mathrm{L}}$ (torsi minimum). Apabila suhu vulkanisasi naik dari $\left(150^{\circ} \mathrm{C}\right.$ ke $\left.160^{\circ} \mathrm{C}\right)$ maka waktu scorch $\left(\mathrm{ts}_{2}\right)$ turun, reaksi vulkanisasi berlangsung sangat cepat. Hasil uji ini sesuai dengan penelitian dari (Hasan et al., 2012). Tahap kedua curing ( $\left.\mathrm{tc}_{90}\right)$, pada kondisi tersebut proses pembentukan ikatan silang berlangsung, terjadi reaksi antara molekul karet dan sulfur membentuk ikatan sulfida (mono-, di- atau poli-). Apabila suhu vulkanisasi naik maka waktu optimum vulkanisasi turun, hal ini sesuai pendapat Fathurrohman et al. (2015). Tahap ketiga adalah overcure. Reaksi overcuring sangat tergantung dari jenis karet, bahan pemvulkanisasi dan suhu. Pada kondisi ideal kurva kesetimbangan vulkanisasi diperoleh dari kurva torsi versus waktu. Beberapa kompon karet menunjukkan sifat tidak ideal, yaitu terjadi reversi (karet menjadi lembek) dan marching (karet menjadi kaku). Menurut (Karaagac et al., 2009) tahap ketiga dapat terjadi tergantung formula dari kompon karet.

Tabel 2 merupakan data karakteristik vulkanisasi komposit NBR pada suhu $150^{\circ} \mathrm{C}$ dan $160^{\circ} \mathrm{C}$. Kenaikan suhu vulkanisasi berpengaruh terhadap waktu scorch, waktu optimum vulkanisasi, torsi minimum, torsi maksimum, delta torsi, dan cure rate index (CRI) dari komposit NBR. Suhu vulkanisasi naik maka ts dan $\mathrm{tc}_{90}$ turun. De- mikian pula ukuran partikel carbon black berbeda akan memberikan waktu scorch, waktu optimum vulkanisasi, torsi minimum, torsi maksimum, delta torsi, dan CRI yang berbeda. Surface area partikel carbon black makin kecil waktu scorch, waktu optimum vulkanisasi, torsi minimum, torsi maksimum, delta torsi, dan CRI naik.

Dari hasil reometer juga dapat diketahui kecepatan vulkanisasi masing-masing komposit yang ditunjukkan pada Gambar 3. Gambar 3 menunjukkan kecepatan vulkanisasi komposit NBR pada suhu $150^{\circ} \mathrm{C}$ dan $160^{\circ} \mathrm{C}$. Komposit NBR tanpa carbon black (NBR 1) memiliki kecepatan vulkanisasi paling rendah bila dibandingkan komposit NBR dengan carbon black. Komposit NBR dengan carbon black N330 (NBR 2) memiliki kecepatan vulkanisasi paling tinggi baik pada suhu vulkanisasi $150^{\circ} \mathrm{C}$ maupun $160^{\circ} \mathrm{C}$ (65,72 dan 94,32 kgf.cm/detik). Komposit NBR 4 (N330/N774) memiliki kecepatan vulkanisasi lebih tinggi dibanding komposit NBR 3 (N774). Mobilitas rantai molekul dipengaruhi oleh besar kecilnya ukuran partikel, makin kecil ukuran partikel maka mobilitas rantai molekul besar makin besar sehingga mempercepat reaksi vulkanisasi. Hal ini sesuai pendapat Li et al. (2008) yang menyimpulkan bahwa kecepatan vulkanisasi dipengaruhi oleh surface area carbon black dan kandungan sulfur pada bahan bahan pengisi, yang menyebabkan terbentuknya ikatan fisika dan kimia.

Karet dengan formulasi berbeda akan memiliki kinetika vulkanisasi berbeda, termasuk bila digunakan jumlah dan ukuran carbon black yang berbeda. Hal ini akan berpengaruh pada interaksi matriks carbon black. Komposi NBR dengan bahan pengisi carbon black N330 nilai torsi lebih besar dibandingkan komposit NBR dengan carbon black N774 tetapi delta torsi paling tinggi adalah komposit NBR dengan carbon black N330/N

Tabel 2. Karakteristik vulkanisasi komposit NBR.

\begin{tabular}{|c|c|c|c|c|c|c|c|c|c|c|}
\hline \multirow{3}{*}{ Vulkanisat } & \multicolumn{10}{|c|}{ Suhu vulkanisasi } \\
\hline & \multicolumn{5}{|c|}{$150^{\circ} \mathrm{C}$} & \multicolumn{5}{|c|}{$160^{\circ} \mathrm{C}$} \\
\hline & $\begin{array}{c}\text { ts }_{2}, \\
\mathrm{~S}\end{array}$ & $\begin{array}{c}\mathrm{tc}_{90}, \\
\mathrm{~s}\end{array}$ & $\begin{array}{c}\mathrm{M}_{\mathrm{L}}, \\
\text { kgf.cm }\end{array}$ & $\begin{array}{c}\mathrm{M}_{\mathrm{H}}, \\
\text { kgf.cm }\end{array}$ & $\begin{array}{l}\text { delta torsi, } \\
\text { kgf.cm }\end{array}$ & $\begin{array}{c}\mathrm{ts}_{2}, \\
\mathrm{~S}\end{array}$ & $\begin{array}{c}\mathrm{tc}_{90} \\
\mathrm{~s}\end{array}$ & $\begin{array}{c}\mathrm{M}_{\mathrm{L}}, \\
\text { kgf.cm }\end{array}$ & $\begin{array}{c}\mathrm{M}_{\mathrm{H}}, \mathrm{kgf} . \\
\mathrm{cm}\end{array}$ & $\begin{array}{c}\text { delta torsi, } \\
\text { kgf.cm }\end{array}$ \\
\hline NBR 1 & 38 & 684 & 2,12 & 52,51 & 50,39 & 19 & 424 & 4,74 & 49,75 & 45,01 \\
\hline NBR 2 & 24 & 780 & 8,35 & 80,31 & 71,96 & 17 & 425 & 4,55 & 75,88 & 71,34 \\
\hline NBR 3 & 33 & 873 & 3,29 & 77,51 & 74,22 & 23 & 498 & 2,62 & 70,54 & 67,92 \\
\hline NBR 4 & 32 & 850 & 3,45 & 81,84 & 78,39 & 20 & 502 & 3,76 & 77,13 & 73,38 \\
\hline
\end{tabular}

$\mathrm{ts}_{2}$ : waktu scorch, $\mathrm{tc}_{90}$ : waktu optimum vulkanisasi, $\mathrm{M}_{\mathrm{L}}$ : torsi minimum, $\mathrm{M}_{\mathrm{H}}$ : torsi maksimum. 


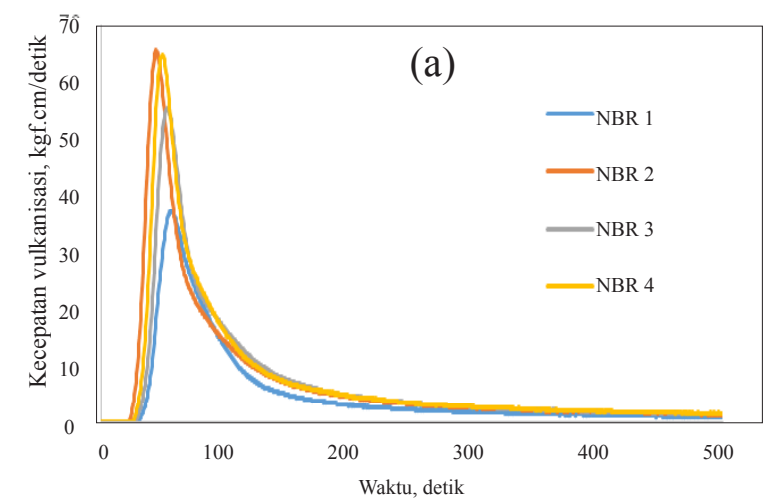

Gambar 3. Kecepatan vulkanisasi komposit NBR

774. Torsi maupun delta torsi naik mengindikasikan ikatan sambung silang yang terbentuk cukup besar. Carbon black dengan ukuran partikel kecil mempunyai surface area maupun surface reactivity cukup tinggi. Hal ini berdampak pada kemampuan interaksi dengan matriks karet cukup tinggi. Apabila suhu vulkanisasi dinaikkan maka delta torsi elastomer naik, hal ini berpengaruh pada interaksi matriks carbon black, stabilitas termal dan terbentuknya ikatan sambung silang. Nilai torsi yang diperoleh selama proses vulkanisasi dari kompon karet terkait dengan formulasi kompon dan suhu vulkanisasi (Toth \& Zanichelli, 1991). Cure rate index (CRI) dihitung dengan rumus (Marković et al., 2007):

$$
\mathrm{CRI}=\frac{100}{\mathrm{tc}_{90}-\mathrm{ts}_{2}}
$$

Komposit NBR tanpa ataupun dengan carbon black mempunyai CRI berbeda, seperti ditunjukkan pada Tabel 3. CRI komposit NBR tanpa carbon black lebih tinggi bila dibandingkan komposit dengan carbon black. Bila ditinjau dari ukuran partikel yang digunakan maka komposit NBR dengan carbon black N330, nilai CRI lebih tinggi dari pada komposit NBR dengan carbon black N774 maupun komposit NBR dengan carbon black campuran keduanya. CRI lebih tinggi menunjukkan kecepatan vulkanisasi lebih cepat atau terjadi penurunan optimum waktu vulkanisasi (Hasan et al., 2012). Suhu vulkanisasi berpengaruh terhadap CRI, suhu vulkanisasi naik maka CRI akan naik hal ini sesuai penelitian Fathurrohman et al. (2015) dan Hasan et al. (2013).

Kinetika pematangan dapat digunakan untuk memprediksi waktu pematangan optimum menggunakan model kinetika berdasarkan hasil eksperimen. Reaksi kimia secara umum dapat dimo-

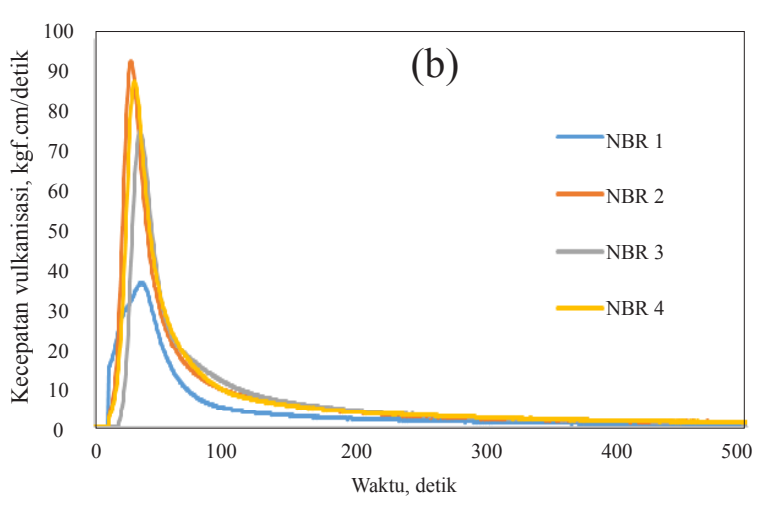

(a) suhu $150^{\circ} \mathrm{C}$ (b) suhu $160^{\circ} \mathrm{C}$.

delkan dalam persamaan diferensial seperti pada persamaan (2):

$$
\frac{\mathrm{d} \alpha}{\mathrm{dt}}=k(T) \cdot f(\alpha)
$$

$\alpha$ adalah konversi yang didapat dari data reometer, dihitung dengan persamaan berikut:

$\alpha=\frac{\mathrm{M}_{\mathrm{t}}-\mathrm{M}_{\mathrm{L}}}{\mathrm{M}_{\mathrm{H}}-\mathrm{M}_{\mathrm{L}}}$

Dalam studi ini, diambil $\mathrm{M}_{\mathrm{t}}$ pada selisih torsi $25 \%$ hingga 45\% (Semsarzadeh et al., 2005). Reaksi vulkanisasi diasumsikan mengikuti orde pertama dan sebanding dengan fraksi material yang tidak berikatan silang $(1-\alpha)$, maka:

$f(\alpha)=(1-\alpha)$

Dengan mensubstitusikan persamaan (4) ke persamaan (2), didapatkan persamaan:

$\frac{\mathrm{d} \alpha}{(1-\alpha)}=k(T) \cdot \mathrm{dt}$

Pengintegralan persamaan (5) menghasilkan:

$\ln \frac{1}{(1-\alpha)}=k \mathrm{t}$

Dengan substitusi persamaan (3) ke persamaan (6) didapat:

$\ln \frac{\mathrm{M}_{\mathrm{H}}-\mathrm{M}_{\mathrm{L}}}{\mathrm{M}_{\mathrm{H}}-\mathrm{M}_{\mathrm{t}}}=k \mathrm{t}$

Dari persamaan (7) dihasilkan grafik dan didapatkan $k$ yang merupakan konstanta kecepatan reaksi.

Dari Tabel 3 diketahui bahwa konstanta kecepatan reaksi komposit NBR dengan carbon black B N330 lebih besar dari N774. Konstanta kecepat- 
Tabel 3. Cure rate index (CRI) dan rate constant vulkanisat NBR.

\begin{tabular}{lrrrr}
\hline \multirow{2}{*}{ Vulkanisat } & \multicolumn{2}{c}{ CRI } & \multicolumn{2}{c}{ Rate constant, $k\left(\mathrm{~s}^{-1}\right)$} \\
\cline { 2 - 5 } & 150 & 160 & 150 & 160 \\
\hline NBR 1 & 9,29 & 14,81 & 0,0120 & 0,0227 \\
NBR 2 & 7,94 & 14,71 & 0,0100 & 0,0204 \\
NBR 3 & 7,14 & 12,63 & 0.0082 & 0.0124 \\
NBR 4 & 7,33 & 12.45 & 0.0092 & 0.0171 \\
\hline
\end{tabular}

an reaksi setiap vulkanisat lebih besar pada suhu $160^{\circ} \mathrm{C}$. Konstanta kecepatan reaksi menunjukkan besarnya kecepatan reaksi. Maka dapat diketahui bahwa carbon black N330 memberikan kecepatan reaksi yang lebih cepat jika dibandingkan carbon black N774 karena diameter partikelnya yang lebih kecil. Campuran CB N330 dan N774 memberikan kecepatan reaksi yang lebih cepat jika dibandingkan CB N774. Diameter partikel kecil (surface area) besar, makin banyak matriks karet yang berikatan dengan carbon black sehingga reaksi sambung silang berjalan lebih cepat.

\section{Sifat Mekanis Komposit NBR}

Dalam penelitian ini juga dipelajari sifat mekanis komposit NBR pada suhu vulkanisasi $150^{\circ} \mathrm{C}$ dan $160^{\circ} \mathrm{C}$. Parameter yang diuji adalah tegangan putus, perpanjangan putus, kekerasan, dan kuat sobek yang ditunjukkan pada Gambar 4-8.

Penambahan carbon black kedalam polimer NBR bertujuan untuk memperbaiki sifat mekanis dari komposit NBR. Sifat carbon black sebagai reinforced filler sangat erat kaitannya dengan bentuk dan ukuran partikel serta interaksi polimer dengan carbon black. Sifat mekanis komposit NBR dipengaruhi oleh jumlah carbon black yang digunakan, dispersi partikel, ukuran partikel, surface area, struktur agregat, dan aktivitas permukaan (Gerspacher, 2009). Sifat mekanis komposit NBR yang mencakup tegangan putus, perpanjangan putus, kekerasan dan kuat sobek pada suhu vulkanisasi $150^{\circ} \mathrm{C}$ dan $160^{\circ} \mathrm{C}$ terdapat pada Gambar 4, 5, 6, dan 7 .

Komposit NBR tanpa carbon black mempunyai sifat mekanis lebih rendah bila dibandingkan dengan komposit NBR dengan tambahan bahan pengisi carbon black. Bila ditinjau dari ukur-an partikel carbon black yang digunakan maka komposit NBR dengan carbon black $\mathrm{N} 330(30 \mathrm{~nm})$, mempunyai nilai sifat mekanis lebih tinggi bila dibandingkan dengan komposit NBR N774 (70

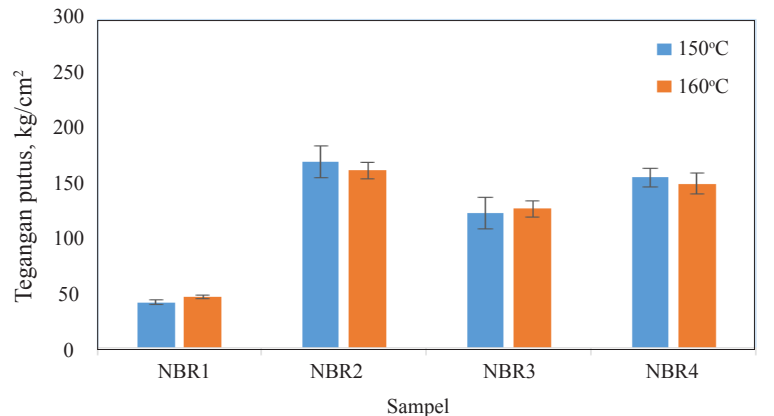

Gambar 4. Tegangan putus komposit NBR pada berbagai jumlah dan jenis carbon black di vulkanisasi pada suhu $150^{\circ} \mathrm{C}$ dan $160^{\circ} \mathrm{C}$.

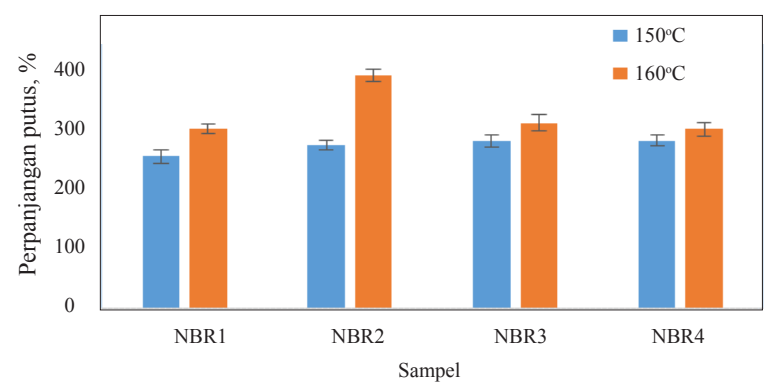

Gambar 5. Perpanjangan putus komposit NBR pada berbagai jumlah dan jenis carbon black yang di vulkanisasi pada suhu $150^{\circ} \mathrm{C}$ dan $160^{\circ} \mathrm{C}$.

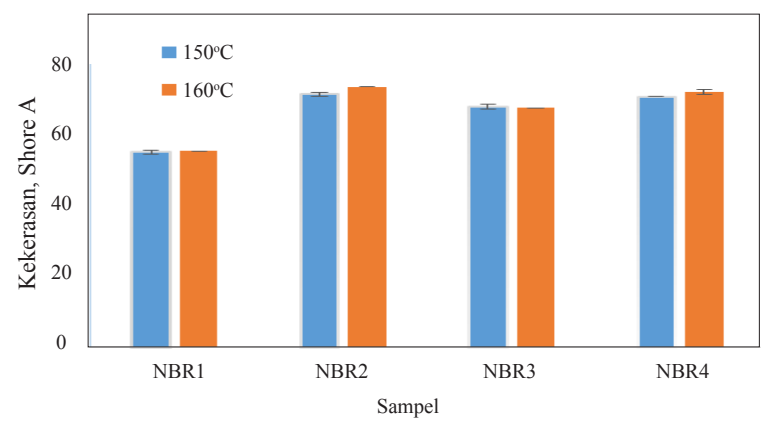

Gambar 6. Kekerasan komposit NBR pada berbagai jumlah dan jenis carbon black yang divulkanisasi pada suhu $150^{\circ} \mathrm{C}$ dan $160^{\circ} \mathrm{C}$.

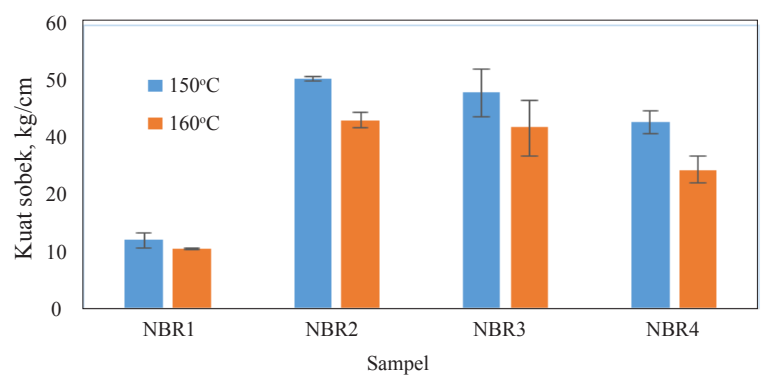

Gambar 7. Kuat sobek komposit NBR pada berbagai jumlah dan jenis carbon black pada suhu vulkanisasi $150^{\circ} \mathrm{C}$ dan $160^{\circ} \mathrm{C}$. 
$\mathrm{nm}$ ) maupun komposit NBR dengan bahan pengisi carbon black N330/N774 hal ini sesuai pendapat (Rattanasom \& Prasertsri, 2009). Suhu vulkanisasi berpengaruh terhadap sifat komposit NBR. Sifat mekanis komposit NBR $\left(150^{\circ} \mathrm{C}\right)$ le-bih besar dari pada komposit NBR $\left(160^{\circ} \mathrm{C}\right)$. Hal ini disebabkan waktu aman untuk proses vulkanisasi (ts $\left.{ }_{2}\right)$ komposit NBR $\left(150^{\circ} \mathrm{C}\right)$ juga lebih lama dari komposit NBR $\left(160^{\circ} \mathrm{C}\right)$ terdapat pada Tabel 2.

\section{KESIMPULAN}

Parameter kinetika vulkanisasi dapat diperoleh dari data hasil uji reometer. Suhu vulkanisasi berpengaruh terhadap parameter kinetika vulkanisasi. Konstanta kecepatan reaksi meningkat dengan kenaikan suhu. Konstanta kecepatan reaksi komposit NBR dengan carbon black N330 lebih besar dibandingkan dengan carbon black N774. Penambahan carbon black N330 dengan ukuran partikel $(30 \mathrm{~nm})$ menurunkan waktu scorch $\left(\mathrm{ts}_{2}\right)$ dan waktu optimum vulkanisasi $\left(\mathrm{t}_{90}\right)$ tetapi memberikan kecepatan vulkanisasi lebih cepat. Suhu vulkanisasi berpengaruh terhadap sifat mekanis komposit NBR. Sifat mekanis komposit NBR $\left(150^{\circ} \mathrm{C}\right)$ lebih baik dari komposit NBR $\left(160^{\circ} \mathrm{C}\right)$. Komposit NBR dengan carbon black N330 mempunyai sifat mekanis tertinggi.

\section{UCAPAN TERIMA KASIH}

Penulis mengucapkan terima kasih kepada Kepala Balai Besar Kulit, Karet dan plastik yang sudah memberikan dana untuk kegiatan penelitian ini.

\section{DAFTAR PUSTAKA}

Ahmed, K., Nizami, S. S., Raza, N. Z., \& Shirin, K. (2012). Cure characteristics, mechanical and swelling properties of marble sludge filled EPDM modified chloroprene rubber blends. Advances in Materials Physics and Chemistry, 2, 90-97. http://dx.doi.org/10.4236/ampc.2012.22016

Akhlaghi, S., Hedenqvist, M. S., Conde Brana, M. T., Bellander, M., \& Gedde, U. W. (2015). Deterioration of acrylonitrile butadiene rubber in rapeseed biodiesel. Polymer Degradation and Stability, 111, 211-222. http://dx.doi.org/10.1016/j. polymdegradstab.2014.11.012

Allegra, G., Raos, G., \& Vacatello, M. (2008). Theories and simulations of polymer-based nanocomposites: From chain statistics to reinforcement. Progress in Polymer Science, 33(7), 683-731. http://dx.doi. org/10.1016/j.progpolymsci.2008.02.003

Chung, J. W., Han, S. J., \& Kwak, S. (2008). Dynamic viscoelastic behavior and molecular mobility of acrylonitrile-butadiene copolymer nanocomposites with various organoclay loadings. Composites Science and Technology, 68(6), 1555-1561. http:// dx.doi.org/10.1016/j.compscitech.2007.10.025

Fathurrohman, M. I., Maspanger, D. R., \& Sutrisno, S. (2015). Vulcanization kinetics and mechanical properties of ethylene propylene diene monomer thermal insulation. Bulletin of Chemical Reaction Engineering \& Catalysis, 10(2), 104-110. http:// dx.doi.org/10.9767/bcrec.10.2.6682.104-110

Gerspacher, M. (2009). Advanced CB characterizations to better understand polymer-filler interaction: A critical survey. Kautschuk Gummi Kunststoffe, 62(5), 233-239.

Hasan, A., Rochmadi, Sulistyo, H., \& Honggokusumo, S. (2012). The effect of rubber mixing process on the curing characteristics of natural rubber. Makara Journal of Technology, 16(2), 109-115. http:// dx.doi.org/10.7454/mst.v16i2.1508

Hasan, A., Rochmadi, Sulistyo, H., \& Honggokusumo, S. (2013). Vulcanization kinetics of natural rubber based on free sulfur determination. Indonesian Journal of Chemistry, 13(1), 21-27.

Indrajati, I. N., Dewi, I. R., \& Irwanto, D. (2012). Pengaruh variasi rasio $\mathrm{HAF} / \mathrm{SRF}$ terhadap sifat vulkanisat NBR. Majalah Kulit, Karet, dan Plastik. 28(2), 59-68. http://dx.doi.org/10.20543/mkkp. v28i2.106

Jovanović, V., Budinski-Simendić, J., SamarzijaJovanović, S., Marković, G., \& Marinović-Cincović, M. (2009). The influence of carbon black on curing kinetics and thermal aging of acrylonitrilebutadiene rubber. Chemical Industry \& Chemical Engineering Quarterly, 15(4), 283-289. http:// dx.doi.org/10.2298/CICEQ0904283J

Jovanović, V., Samarzija-Jovanović, S., BudinskiSimendić, J., Marković, G., \& Marinović-Cincović, M. (2013). Composites based on carbon black reinforced NBR/EPDM rubber blends. Composites Part B: Engineering, 45(1), 333-340. http://dx.doi. org/10.1016/j.compositesb.2012.05.020

Karaagac, B., Inal, M., \& Deniz, V. (2009). Artificial neural network approach for predicting optimum cure time of rubber compounds. Materials \& Design, 30(5), 1685-1690. http://dx.doi.org/10.1016/j. matdes.2008.07.010

Li, Z. H., Zhang, J., \& Chen, S. J. (2008). Effects of carbon blacks with various structures on vulcanization and reinforcement of filled ethylenepropylene-diene rubber. Express Polymer Letters, 2(10), 695-704. http://dx.doi.org/10.3144/ expresspolymlett.2008.83

Marković, G., Marinović-Cincović, M., Radovanović, B., \& Budinski-Simendić, J. (2007). Rheological and mechanical properties of wood flour filled polyisoprene/chlorosulphonated polyethylene rubber blends. Chemical Industry \& Chemical 
Engineering Quarterly, 13(4), 186-191. http:// dx.doi.org/10.2298/CICEQ0704186M

Mostafa, A., Abouel-Kasem, A., Bayoumi, M. R., \& ElSebaie, M. G. (2009). The influence of CB loading on thermal aging resistance of SBR and NBR rubber compounds under different aging temperature. Materials \& Design, 30(3), 791-795. http://dx.doi. org/10.1016/j.matdes.2008.05.065

Rajasekar, R., Pal, K., Heinrich, G., Das, A. \& Das, C. K. (2009). Development of nitrile butadiene rubbernanoclay composites with epoxidized natural rubber as compatibilizer. Materials \& Design, 30 (9), 3839-3845. http://dx.doi.org/10.1016/j. matdes.2009.03.014

Rattanasom. N., \& Prasertsri, S. (2009). Relationship among mechanical properties, heat ageing resistance, cut growth behaviour and morphology in natural rubber: Partial replacement of clay with various types of carbon black at similar hardness level. Polymer Testing, 28(3), 270-276. http:// dx.doi.org/10.1016/j.polymertesting.2008.12.010
Semsarzadeh, M. A., Bakhshandeh, G. R., \& Ghasemzadeh-Barvarz, M. (2005). Effect of carbon black on rate constant and activation energy of vulcanization in EPDM/BR and EPDM/NR blends. Iranian Polymer Journal, 14(6), 573-578.

Toth, W. J., Chang J. P., \& Zanichelli, C. (1991). Finite element evaluation of the state of cure in a tire. Tire Science and Technology, 19(4), 178-212. http:// dx.doi.org/10.2346/1.2141715

Yuan, X., Shen, F., Wu, G., \& Wu, C. (2007). Effects of acrylonitrile content on the coordination crosslinking reaction between acrylonitrile-butadiene rubber and copper sulfate. Materials Science and Engineering: A, 459 (1-2), 82-85. http://dx.doi.org/10.1016/j. msea.2007.01.036

Zaimova, D., Bayraktar, E., \& Dishovsky, N. (2011). State of cure evaluation by different experimental methods in thick rubber parts. Journal of Achievements in Materials and Manufacturing Engineering, 44(2), 161-167. 